\title{
The Effect of a Rehabilitation Program Supported by a Hydrotherapy Method on the Speed of Patient's Recovery with Lumbar Cartilage
}

\section{Dr. Lecturer. Walid Hussein Hassan}

\section{Introduction and research problem}

The healthy body is not only a sign of good health; it is also a vital influence not only on the ability to perform work positively, but also as a powerful indicator of affordability, which positively affects the economic situation

Lower back pain is one of the most common health problems among people and comes in second place after colds as a reason for hesitating doctors to seek treatment.

The latest statistics indicate that more than $80 \%$ of the population of the earth were suffering or will suffer from back pain attacks in a period of their lives (30:10) (21:7)

Statistics also indicate that the disease causes a disability in the UK to about 290 thousand cases and the treatment of these cases annually about one billion pounds and also suffer more than 65 million Americans of back pain, and the cost of treatment to 50 billion US dollars each year, On the national economy (54:27.)

In Egypt, although there are no accurate statistics indicating the number of patients, it can be said that more than five million Egyptians are often referred to bone clinics for complaints of spinal pain, including about one million admitted to hospitals for treatment $(54: 20$.

The pain is not only on the patient but on the national economy. Millar (2002) points out that the pain in Britain has caused 300,000 people to lose their jobs and 13 million hours of work per year. Millar (2002) (32) days due to low back pain and that of every (200) workers there is only one worker is cut off from work. (98:32)

The cartilage slide occurs when there is greater pressure on the cartilage, leading to the emergence of the gelatin center outside the center of the cartilage represents a bulge on the nerves branching of the spinal cord causing severe pain and loss of motor functions of the spine, and may affect the lower limbs causing foot fall and inability to control On them and use them (32:35)

It has been used since the ancient times as it has been used in the treatment of weakened muscles and paralyzed limbs. Floating on water allows the body to move easily and easily from the ground (23: 8)

The benefits of hydrotherapy for high-level athletes and the levels of rehabilitation and treatment by performing a few times in the water medium through the intensity of rapid training and thus gaining high fitness, which in turn avoid injury and help to return to normal (stage of recovery) after the performance of competitions or Heavy training or hydrotherapy can be performed on a daily basis, increasing the training time and increasing some of the kinetic abilities (strength, speed, flexibility, endurance)

Hydrotherapy is an aid to various exercises. The process of concentrated hydrotherapy affects the surface of the body and its organs, not only the blood circulation and body temperature, but also its positive effect on the metabolism of the body and the nervous system and even the composition of the blood components itself and endocrine secretions. : 22)

The idea of the Jacuzzi (aquatic therapy) is a tube out of which the waves of water warm or cold to decompress the convulsions and other cold waves to decompose nerve convulsions by pushing by a pump, which in turn pump water in the basin at multiple speeds as desired, in the form of swirls Circular, through these holes, to massage the body immersed in the water of this basin as the circular water movement that works water vibrations help to relax the muscles and can be used only cold or hot water or combined together. 
The spin system is usually operated by a very small pump, or low speed setting in a two-speed pump. The filter is made of paper and is very small compared to pool filters. The jet water treatment system operates on a booster pump, or a high-speed setting to prepare the two-speed pump. The water is sucked from multiple suction points in the foot pads to the Jacuzzi, pulled through a paper filter, pumped through the pump, sent through the heater and then returned to the spa through jet aircraft and therapeutic aircraft.

The importance of treatment and rehabilitation of the movement, which ended Mohammed Kadri Bakri and Siham al-Ghamra (2005), is that the treatment of the regulated movement is one of the basic natural means in the field of integrated treatment and the process of treatment and rehabilitation of locomotion depends on the various kinds of exercise (48: 78.)

It is clear that back pain is a problem that is occurring throughout the world and in Egypt as well, and that surgical intervention alone is not sufficient to permanently and permanently remove pain and that it is necessary to complete treatment and rehabilitation with physical movement, which includes motor therapy, massage and hydrotherapy( .

The importance of the research through the observations of the field researcher and friction with this category through the academic and scientific study and the work done by the researcher is the rehabilitation of these patients to try to access the design of a program of motor therapy and hydrotherapy based on the employment of the movement of the standard treatment and rehabilitation in addition to therapeutic massage based on Scientific foundations to address the problem of rehabilitation of patients with low back pain of patients with gastro esophageal slip after surgical intervention and to determine how quickly recover their recovery, as the reduction factor of the period of rehabilitation is of great importance for the work and production and health of the injured.

\section{Research goal}

The aim of this study is to identify the effect of a rehabilitation program supported by a hydrotherapy method on the speed of recovery of patients with lumbar cartilage

\section{Research hypotheses}

There were statistically significant differences between mean and post measurements in the level of pain of those with lumbar disc herniation.

There were statistically significant differences between mean and post measurements of muscle strength (for the back - for both men and the abdomen) for those with lumbar cartilage.

There were statistically significant differences between mean and post measurements of the spine elasticity of the lumbar spine.

\section{Research Plan and Procedures: \\ Research Methodology}

The researcher used the experimental method of designing the post-pre measurement for a single experimental group in view of the nature of the research and the achievement of its goals and objectives.

\section{Society and sample research}

The research community was chosen from the second-degree lumbar discoloration group in Al Gharbia Governorate and the patients at Rashid Specialist Hospital in the Physical Therapy and Rehabilitation Department in Al-Gharbia Governorate in Mahalla AlKobra.

The age group ranged from (48-55) years. The research community reached (20) 10) were infected, in addition to (8) infected for the exploratory study of the research. 
Table (1) The mean, median and standard deviation of growth rates With lumbar discoloration $(\mathbf{N}=\mathbf{2 0})$

\begin{tabular}{l|l|l|l|l|c|c}
\hline \hline Variables & Measurements & $\begin{array}{l}\text { Measurin } \\
\text { g unit }\end{array}$ & SMA & $\begin{array}{l}\text { Media } \\
\text { tor }\end{array}$ & $\begin{array}{l}\text { standard } \\
\text { deviatio } \\
\mathrm{n}\end{array}$ & $\begin{array}{l}\text { Torsion } \\
\text { coeffici } \\
\text { ent }\end{array}$ \\
\hline \hline \multirow{2}{*}{$\begin{array}{l}\text { Physical } \\
\text { variables }\end{array}$} & Height & $\mathrm{Cm}$ & 168.20 & 168.00 & 2.01 & 0.298 \\
\cline { 2 - 7 } & Weight & $\mathrm{Kg}$ & 81.25 & 81.00 & 3.21 & 0.233 \\
\hline \hline
\end{tabular}

Table (1) shows that the values of the torsion coefficients for the growth rates under study for the sample of the study are limited to $( \pm 3)$, which indicates that the distribution of patients in these variables is moderate.

Table (2) The mean, median and standard deviation at the level of pain with lumbar discoloration $(\mathbf{N}=\mathbf{2 0})$

\begin{tabular}{l|l|l|l|l|c|c}
\hline \hline Variables & Measurements & $\begin{array}{l}\text { Measurin } \\
\text { g unit }\end{array}$ & SMA & $\begin{array}{l}\text { Media } \\
\text { tor }\end{array}$ & $\begin{array}{l}\text { standard } \\
\text { deviatio } \\
\mathrm{n}\end{array}$ & $\begin{array}{l}\text { Torsion } \\
\text { coefficie } \\
\text { nt }\end{array}$ \\
\hline \hline \multirow{2}{*}{$\begin{array}{l}\text { Degree } \\
\text { of pain }\end{array}$} & From standing & Degree & 6.98 & 6.95 & 0.91 & 0.0989 \\
\cline { 2 - 7 } & From sitting & Degree & 7.10 & 7.00 & 0.19 & 1.578 \\
\cline { 2 - 7 } & From lying & Degree & 6.54 & 6.50 & 0.18 & 0.666 \\
\hline \hline
\end{tabular}

It is clear from Table (2) that the values of the torsion coefficients for the level of pain in the research sample are limited to $( \pm 3)$, indicating the moderation of the distribution of the patients in these variables.

Table (3) Mean median mean and standard deviation of muscle strength level In patients with lumbar discoloration $N=\mathbf{2 0}$

\begin{tabular}{l|l|l|l|l|c|c}
\hline \hline $\begin{array}{l}\text { Variable } \\
\mathrm{s}\end{array}$ & Measurements & $\begin{array}{l}\text { Measurin } \\
\mathrm{g} \text { unit }\end{array}$ & $\mathrm{SMA}$ & $\begin{array}{l}\text { Media } \\
\text { tor }\end{array}$ & $\begin{array}{l}\text { Standard } \\
\text { deviatio } \\
\mathrm{n}\end{array}$ & $\begin{array}{l}\text { Torsion } \\
\text { coeffici } \\
\text { ent }\end{array}$ \\
\hline \hline & $\begin{array}{l}\text { Strength of back } \\
\text { muscles }\end{array}$ & $\mathrm{Kg}$ & 33.25 & 33.00 & 1.36 & 0.551 \\
\cline { 2 - 7 } $\begin{array}{l}\text { Muscle } \\
\text { strength }\end{array}$ & $\begin{array}{l}\text { Strength of } \\
\text { abdominal muscles }\end{array}$ & $\mathrm{Kg}$ & 21.36 & 21.30 & 1.30 & 0.138 \\
\cline { 2 - 7 } & $\begin{array}{l}\text { Strength of the } \\
\text { muscles of the feet }\end{array}$ & $\mathrm{Kg}$ & 34.28 & 34.20 & 1.39 & 0.172 \\
\hline \hline
\end{tabular}

It is clear from Table (3) that the values of the torsion coefficients of the muscle strength level in the research sample are limited to $( \pm 3)$, which indicates the moderation of the distribution of the patients in these variables. 
Table (4) Arithmetic mean, median and standard deviation Flexibility of lumbar discoloration $\mathrm{N}=\mathbf{2 0}$

\begin{tabular}{|c|c|c|c|c|c|c|}
\hline $\begin{array}{l}\text { Variable } \\
\text { s }\end{array}$ & Measurements & $\begin{array}{c}\text { Measuring } \\
\text { unit }\end{array}$ & SMA & $\begin{array}{l}\text { Mediat } \\
\text { or }\end{array}$ & $\begin{array}{c}\text { standard } \\
\text { deviatio } \\
n\end{array}$ & $\begin{array}{c}\text { Torsion } \\
\text { coefficie } \\
n t\end{array}$ \\
\hline \multirow{4}{*}{$\begin{array}{c}\text { Flexibili } \\
\text { ty }\end{array}$} & $\begin{array}{l}\text { Flexibility of the spine } \\
\text { (front) }\end{array}$ & $\mathrm{Cm}$ & 10.25 & 10.00 & 0.62 & 1.20 \\
\hline & Flexible backbone (back) & $\mathrm{Cm}$ & 15.32 & 15.10 & 0.39 & 1.69 \\
\hline & $\begin{array}{l}\text { Flexibility of the spine to } \\
\text { the right }\end{array}$ & $\mathrm{Cm}$ & 45.39 & 45.30 & 3.10 & 0.087 \\
\hline & $\begin{array}{l}\text { The flexibility of the left } \\
\text { spine }\end{array}$ & $\mathrm{Cm}$ & 43.28 & 43.20 & 2.15 & 0.119 \\
\hline
\end{tabular}

Table (1) shows that the values of torsion coefficients for the elasticity level in the study sample are limited to $( \pm 3)$, which indicates the moderation of the distribution of patients in these variables.

First: Tools and tools used:

-Resistometer to measure height and weight.

- V-S scale.

-Swiss balls diameter (85) $\mathrm{cm}$.

-Dynamometer to measure the strength of the two back muscles.

-P-198 Combo Abdominal Back Extension w / ROM to measure the strength of the abdominal muscles.

-Educational swimming pool.

- Tape measure.

-Adjustable wooden box to measure the flexibility of the spine.

- Digital clock to determine the times of each exercise.

-Jacuzzi

Tests used in research: Attachment (2)

.-V-S test by optical symmetry scale.

-the test weighed on the imam to measure the elasticity of the front spine.

-the test of the strain on the successor to measure the flexibility of the front spine.

- .Side-by-side (left-right side) test to measure the elasticity of the lateral spine.

-Test dynamometer to measure muscle strength of the two men.

-Test dynamometer to measure the strength of muscle back.

.-P-198 Combo Abdominal Back Extension w / ROM to measure the strength of the abdominal muscles.

\section{Questionnaires used:}

-Expert feedback form on the tests used in the research. Annex (3)

-Expert feedback questionnaire on the content of the proposed rehabilitation program for patients with lumbar discoloration.Annex (3)

\section{Proposed program using rehabilitation and hydrotherapy exercises}

\section{Program Goals-:}

1-To identify the effect of the use of training exercises and hydrotherapy on the recovery rate of the lips of patients with slipped cartilage research sample.

2-To identify the effect of the use of training exercises on the degree of pain in patients with slipped cartilage

\section{Building the program:}

1-The content of the exercise should match the sample of the study as it has a slipped disc

2-taking into account the individual differences between the injured. 
3-The program should be flexible enough to be modified if necessary.

4-The program should achieve the goal set for improving the efficiency and functionality of the sample and reducing the pain of the patients.

5-Taking into account the principle of diversity in the performance of training within the training unit so as not to feel bored and hesitant due to the application of the proposed rehabilitation program using the exercises of balance motor.

-Implementation phases of the program

-The program was divided into three phases:

*First phase (three weeks) (three units per week) (Unity time 40 minutes)

\section{This phase aims to:}

-Reduce the aggravation of infection

-Relieve pain on the cartilaginous segment

-Development of fixed muscle strength

-Improve muscle tone

*Components

-Massage for back and back and front muscles

-Putting hot and cold compresses

-Permanent motor exercises for the lower back area in water and out of water

-Make ice compresses for five minutes on the lower back area of the first stage

Table (5)

The content of the proposed preparatory program

\begin{tabular}{l|l|l}
\hline \hline Serial & Limits & Time \\
\hline \hline$r$ & Content of the first stage & $(45) \mathrm{m}$ \\
\hline$r$ & $\begin{array}{l}\text { General motor exercises Firm exercises for the } \\
\text { muscles surrounding the back }\end{array}$ & $(21) \mathrm{m}$ \\
\hline$r$ & $\begin{array}{l}\text { Water pushing } \\
\text { feecial massage for the muscles of the back and }\end{array}$ & $(15) \mathrm{m}$ \\
\hline \hline
\end{tabular}

*The second stage (three weeks) (three units per week) (unit time 50 minutes)

This phase aims to:

-Relieve pain and reduce aggravation of injury

-Increased elasticity of the lower back muscles

-Strengthen the muscles of the abdomen, back and legs

-Revitalize blood circulation and improve the functioning of the lymphatic system

*Components

-Full massage for the back and legs

-Stand in the water and work exercises fixed and moving in the water

-Work cold and hot water payment of the injured

-Constant and moving exercises outside the water with moderate intensity under the limits of the mother

Make ice compresses for five minutes on the lower back area

Table (6)

Determinants of the second phase of the qualifying program

\begin{tabular}{l|l|l}
\hline \hline Serial & Limits & Time \\
\hline \hline & \multicolumn{1}{|c}{ Content of Phase III } & (50) $\mathrm{m}$ \\
\hline $1-$ & $\begin{array}{l}\text {-Motor exercises with medium strength of the } \\
\text { immunity area and back muscles } \\
\text {-Moving exercises with light erections }\end{array}$ & (23) m \\
& \multicolumn{2}{|c|}{} \\
\hline \hline
\end{tabular}




\begin{tabular}{l|l|l}
\hline \hline & Underwater exercises & \\
\hline $3-$ & Hydrotherapy & $(15) \mathrm{m}$ \\
\hline $4-$ & Massage for the muscles of the legs and back & (9) $\mathrm{m}$ \\
\hline $5-$ & Put the snow on the lower back & (3) $\mathrm{m}$ \\
\hline \hline
\end{tabular}

*Third stage (three weeks) (three units per week) (unit time 60 minutes)

Aims to:

-Reduce the aggravation of the mother

-Strengthen the muscles of the lower back

-Strengthen the muscles of the back completely

-Strengthen the front and back muscles of the two men

-Increased elasticity of the back muscles

\section{The ingredients:}

-Full massage work for the back and front and back muscles of the two men

-Perform motor exercises in the swimming pool

-Swimming pool for the injured

-Water treatment sessions

-Perform motor exercises on the ground

-The work of strengthening exercises by weights and appliances

-Put ice on the lower back area for 5 minutes

Table (7) Phase III of the proposed program

\begin{tabular}{|c|c|c|}
\hline Serial & Limits & Time \\
\hline & The contents of III phase & (60) m \\
\hline 1 & Warming & $(5) \mathrm{m}$ \\
\hline 2 & $\begin{array}{cc}\text {-Kinetic exercises } \\
\text {-Moving exercises with gradual resistance } \\
\text {-Water Resistant Exercises }\end{array}$ & (20) $\mathrm{m}$ \\
\hline 3 & Hydrotherapy & $(20) \mathrm{m}$ \\
\hline 4 & Massage for the muscles of the feet and back & $(10) \mathrm{m}$ \\
\hline 5 & Put the snow on the lower back & $(5) \mathrm{m}$ \\
\hline
\end{tabular}

Pre measurements

The researcher carried out the pre measurements for the individual of the research sample in the physical variables (muscle strength - elasticity) degree of pain on 15/9/2016 at the center of the elite physiotherapy.

\section{Basic experience:}

The proposed rehabilitation program was carried out with the use of hydrolysis exercises with a slipped slide of the sample of the study on the members of the experimental group at a rate of (2) months for a period of (9) weeks, three units per week, from 16/9/2016 to 19/11/2005. 2016 days (Saturday - Monday - Wednesday) to identify the research sample.

\section{Search steps:}

-Period of application of the proposed qualifying program $=2$ months $=9$ weeks.

-Number of qualifying units per week $=3$ units

-Number of qualifying units during the proposed program $=3$ units $\times 9$ weeks $=28$ units.

-The average time of qualifying unit in the program from (40 to 60) minutes

-The contents of the proposed rehabilitation program included a simple exercise group for the development of the level of muscle strength and flexibility of the injured sample of the research.

-Training in performance in light of the scientific foundations of sports rehabilitation. 
-Taking into account the ease of exercises within the unit to suit the sample of the research, especially as they are infected.

Dimension measurements:

The dimension measurements were carried out in the same order of pre measurements on 19/11/2016.

View and discuss the results

First: Display the results

Table (8) Indication of the differences between the pre and post measurements of the sample members at the grade level Pain for people with lumbar cartilage $N=12$

\begin{tabular}{l|l|l|l|l|l|l|l|l|l}
\hline \hline $\begin{array}{l}\text { Variabl } \\
\text { es }\end{array}$ & $\begin{array}{l}\text { Measurem } \\
\text { ent unit }\end{array}$ & \multicolumn{2}{l|}{$\begin{array}{l}\text { Pre } \\
\text { measurem } \\
\text { ent }\end{array}$} & $\begin{array}{l}\text { Post } \\
\text { measurem } \\
\text { ent }\end{array}$ & $\begin{array}{l}\text { Differen } \\
\text { ce } \\
\text { between } \\
\text { average } \\
\mathrm{s}\end{array}$ & $\begin{array}{l}\text { Improvem } \\
\text { ent rate }\end{array}$ & $\begin{array}{l}\text { Calculat } \\
\text { ed value } \\
(\mathrm{t})\end{array}$ & $\begin{array}{l}\text { Level of } \\
\text { significa } \\
\text { nce }\end{array}$ \\
\cline { 3 - 10 } & $\mathrm{S} \pm$ & $\pm \mathrm{E}$ & $\mathrm{S} \pm$ & $\pm \mathrm{E}$ & & & & & \\
\hline \hline $\begin{array}{l}\text { From } \\
\text { standin } \\
\mathrm{g}\end{array}$ & Degree & 6.98 & 0.91 & 4.42 & 0.12 & 2.56 & $36.67 \%$ & 5.21 & Indicated \\
\hline $\begin{array}{l}\text { From } \\
\text { sitting }\end{array}$ & Degree & 7.10 & 0.19 & 5.22 & 0.31 & 1.88 & $26.47 \%$ & 5.39 & Indicated \\
\hline $\begin{array}{l}\text { From } \\
\text { lying }\end{array}$ & Degree & 6.54 & 0.18 & 4.10 & 0.18 & 2.44 & $37.30 \%$ & 5.21 & Indicated \\
\hline \hline
\end{tabular}

- Tabular value $(\mathrm{t}=0.05)=1.812$

Table (8) shows that statistically significant differences were found at the 0.05 level between the pre and post-experimental parameters of the experimental group at the level of pain of the patients with lumbar cartilage. The value of $(\mathrm{T})$ was higher than the tabular value at the significance level $(0.05)$ indicates that there are statistically significant differences at $(0.05)$ between the pre measurements.

Table (9)

Indication of the differences between the pre and post measurements of the sample members at the level of forceMusculoskeletal dysplasia

$\mathrm{N}=12$

\begin{tabular}{c|c|c|c|c|c|c|c|c|c}
\hline \hline \multirow{2}{*}{$\begin{array}{c}\text { Variable } \\
\mathrm{s}\end{array}$} & $\begin{array}{c}\text { Measureme } \\
\mathrm{nt} \text { unit }\end{array}$ & \multicolumn{2}{|c|}{$\begin{array}{c}\text { Pre } \\
\text { measureme }\end{array}$} & \multicolumn{2}{|c|}{$\begin{array}{c}\text { Post } \\
\text { measureme } \\
\mathrm{nt}\end{array}$} & $\begin{array}{c}\text { Differen } \\
\text { ce } \\
\text { between } \\
\text { averages }\end{array}$ & $\begin{array}{c}\text { Improveme } \\
\text { nt rate }\end{array}$ & $\begin{array}{c}\text { Calculat } \\
\text { ed value } \\
(\mathrm{t})\end{array}$ & $\begin{array}{c}\text { Level of } \\
\text { significan } \\
\text { ce }\end{array}$ \\
\cline { 2 - 9 } & $\mathrm{S} \pm$ & $\pm \mathrm{E}$ & $\mathrm{S} \pm$ & $\pm \mathrm{E}$ & & & \\
\hline \hline $\begin{array}{c}\text { Strength } \\
\text { of back } \\
\text { muscles }\end{array}$ & $\mathrm{kg}$ & $\begin{array}{c}33.2 \\
5\end{array}$ & $\begin{array}{c}1.3 \\
6\end{array}$ & $\begin{array}{c}41.3 \\
6\end{array}$ & 0.9 & 8.11 & $19.60 \%$ & 4.85 & Indicated \\
\hline $\begin{array}{c}\text { Strength } \\
\text { of } \\
\text { abdomin } \\
\text { al } \\
\text { muscles }\end{array}$ & $\mathrm{kg}$ & $\begin{array}{c}21.3 \\
6\end{array}$ & $\begin{array}{c}1.3 \\
0\end{array}$ & $\begin{array}{c}29.3 \\
2\end{array}$ & 0.9 & 7.96 & $27.14 \%$ & 5.69 & Indicated \\
\hline Strength & $\mathrm{kg}$ & 34.2 & 1.3 & 41.1 & 1.1 & 6.87 & $16.69 \%$ & 4.62 & Indicated \\
\hline \hline
\end{tabular}




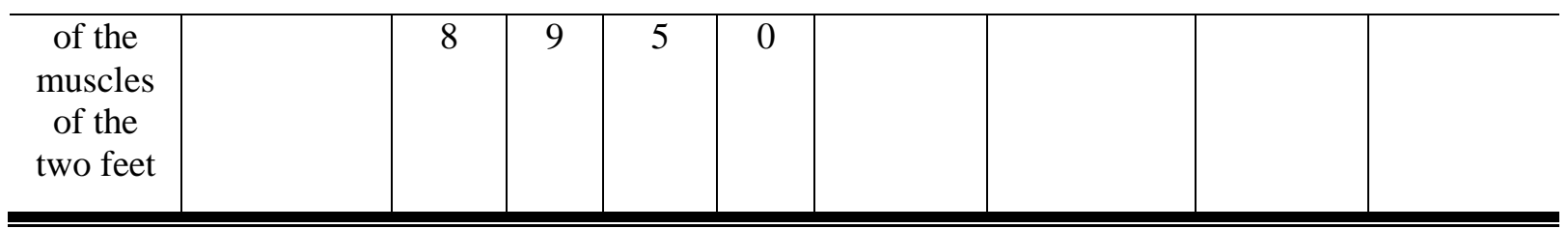

- Tabular value $(\mathrm{t}=0.05)=1.812$

Table (9) shows statistically significant differences at the significance level of 0.05 between the pre and post-experimental measurements of the experimental group at the level of muscle strength of those with lumbar cartilage. The value of (t) was higher than the tabular value of (0.05) Indicates that there are statistically significant differences at $(0.05)$ between the pre measurements.

Table (10)

Indication of the differences between the pre and post measurements of the sample in the level of flexibility For patients with lumbar cartilage $\mathbf{N}=12$

\begin{tabular}{|c|c|c|c|c|c|c|c|c|c|}
\hline \multirow[t]{2}{*}{ Variables } & \multirow[t]{2}{*}{$\begin{array}{l}\text { Measuremen } \\
\text { t unit }\end{array}$} & \multicolumn{2}{|c|}{$\begin{array}{c}\text { Pre } \\
\text { measuremen } \\
\mathrm{t}\end{array}$} & \multicolumn{2}{|c|}{$\begin{array}{c}\text { Post } \\
\text { measuremen } \\
\mathrm{t}\end{array}$} & \multirow{2}{*}{$\begin{array}{l}\text { Differenc } \\
\text { e between } \\
\text { averages }\end{array}$} & \multirow[t]{2}{*}{$\begin{array}{l}\text { Improvemen } \\
\text { t rate }\end{array}$} & \multirow{2}{*}{$\begin{array}{l}\text { Calculate } \\
\text { d value } \\
(\mathrm{t})\end{array}$} & \multirow{2}{*}{$\begin{array}{c}\text { Level of } \\
\text { significanc } \\
\mathrm{e}\end{array}$} \\
\hline & & $\mathrm{S} \pm$ & $\pm \mathrm{E}$ & $\mathrm{S} \pm$ & $\pm \mathrm{E}$ & & & & \\
\hline $\begin{array}{l}\text { Flexibilit } \\
\text { y of the } \\
\text { spine } \\
\text { (front) }\end{array}$ & $\mathrm{Cm}$ & 10.25 & 0.62 & 15.36 & 0.21 & 5.11 & $33.26 \%$ & 5.69 & Indicated \\
\hline $\begin{array}{c}\text { Flexible } \\
\text { backbone } \\
\text { (back) }\end{array}$ & $\mathrm{Cm}$ & 15.32 & 0.39 & 21.36 & 0.17 & 6.04 & $28.27 \%$ & 5.34 & Indicated \\
\hline $\begin{array}{l}\text { Flexibilit } \\
\text { y of the } \\
\text { spine to } \\
\text { the right }\end{array}$ & $\mathrm{Cm}$ & 45.39 & 3.10 & 52.39 & 0.32 & 7.00 & $13.36 \%$ & 5.17 & Indicated \\
\hline $\begin{array}{l}\text { The } \\
\text { flexibility } \\
\text { of the left } \\
\text { spine }\end{array}$ & $\mathrm{Cm}$ & 43.28 & 2.15 & 51.39 & 0.28 & 8.11 & $15.78 \%$ & 5.63 & Indicated \\
\hline
\end{tabular}

- Tabular value $(\mathrm{t}=0.05)=1.812$

Table (10) shows statistically significant differences at the significance level of 0.05 between the pre and post-experimental measurements of the experimental group in the elasticity level for those with lumbar cartilage. The value of $(t)$ was higher than the tabular value at $(0.05)$ There were statistically significant differences at $(0.05)$ between the pre measurements.

\section{Discussion of results}

Table (8) shows that statistically significant differences were found at the 0.05 level between the pre and post-experimental parameters of the experimental group at the level of pain of the patients with lumbar cartilage.

The value of $(\mathrm{T})$ was higher than the tabular value at the significance level (0.05) indicates that there are statistically significant differences at $(0.05)$ between the pre measurements. The researcher attributed this result to the use of the proposed program for training exercises and water propulsion 
This is in line with what Muhammad Qadri (2000) indicated that one of the goals of sports rehabilitation is to restore the kinetic memory of the injured organ, as well as to restore the speed of the underlying systolic response to the injured part, as well as to restore the allergic reaction to the injured part (16: 89)

There is no doubt that the program of motor therapy and hydrotherapy developed by the researcher added a lot of easing the pressure on the lumbar region and thus relieve the pain of the lumbar region and explained that in the rate of improvement.

Randolph (2000) noted that the weakness of the back and abdomen muscles increases back pain (33: 238). Ahmed Khaled (2000) noted that the exercises of the actual lower abdominal muscles have the best effect on lower back pain resistance (2: 157)

This is in line with what Marcia K (2005) and Wael Ibrahim (2007) have shown that exercise with other treatments has a better effect in treating and alleviating low back pain $(75: 21)$

According to Muhammad Qadri (2006), therapeutic exercises improve the muscular sense and regulate the work of the muscles responsible for work and movement. Thus, regulating the function of the motor nerves. By repeating the movement, the nerve signals move easily between the nerve fibers, helping the injured member return to normal condition to perform his function. Complete (17: 17)

Thus, the first hypothesis of the study, which states that there are statistically significant differences between the averages of the pre and post measurements in the degree of pain of the patients with lumbar cartilage

Table (9) shows statistically significant differences at the significance level of 0.05 between the pre and post-experimental measurements of the experimental group at the level of muscle strength of those with lumbar cartilage. The value of $(\mathrm{t})$ was higher than the tabular value of (0.05) Indicates that there are statistically significant differences at $(0.05)$ between the pre measurements.

The researcher returns this result to the water resistance used by the researcher within the rehabilitation program, which contributed to the rapid recovery of the lips of the patients of lumbar cartilage.

The researcher refers to the change or change in the level of muscular strength in people who are infected with the research sample as a result of their exposure to the application of the proposed rehabilitation program, which is based on the principles and principles of upgrading the level of sports qualification in a sound and systematic manner that improved the functional abilities of the injured and also by relying on the group of exercises fixed and moving within Rehabilitation Program sThat the level of change in the functional efficiency of the lower back area depends some of the exposure to injury to two factors, the first is the severity of the injury and the other is the quality of the exercises used within the rehabilitation program applied to the injured (96:3)

And that it is important to take into account the programs of rehabilitation sports put therapeutic exercises within the rehabilitation program in the direction of the movement nature injured part and always begin using the exercise and help and then exercise and movement of the injured and finally use the training exercises using resistors (69:12)

As it is noted in the rehabilitation programs that the development of muscle groups required by the nature of performance and neglect the development of other muscle groups and therefore may occur recurrence of infection and there or, in the development of muscle groups to take full rehabilitation of the affected area. (101: 18)

This is confirmed by the results of the study of Ibrahim Hassan (2015) (1) Anwar Fathi (2008) (4) that the practice of exercise regularly have a positive and effective effect on 
improving and increasing the strength of the muscles of the two men and the back and abdomen which helps to strengthen the muscles of the lumbar region Of cartilaginous clots.

Several studies have suggested that the use of some physical therapy methods, such as massage, shortwave, and infrared, has an effective role in relieving lower back pain. The study of Tariq Abdul-Khaliq (2009) (9) Back and strengthen the muscles to the maximum degree.

Table (10) shows statistically significant differences at the significance level of 0.05 between the pre and post-experimental measurements of the experimental group in the elasticity level for those with lumbar cartilage. The value of $(t)$ was higher than the tabular value at $(0.05)$ there were statistically significant differences at $(0.05)$ between the pre measurements. The researcher attributed this result to the use of the proposed rehabilitation program on the sample of the infected patients, which included the exercises of lengthening inside the water, which contributed to the development of flexibility positively.

In this regard, the results of the study of Azza Fouad Shura (2006) (12) indicate that the improvement of lower back pain resulting from slipped cartilage achieved the best results by the treatment of cough and then massage and therapeutic exercises and because the researcher did not include in the treatment program method of tension, but Fahey (2000) The study found that the practice of lumbar discoloration for a therapeutic exercise program had an effect on the treatment of dysfunction of the lumbar vertebrae and that about $92 \%$ of the total sample of the study had improved their condition and were able to return to normal or similar to pre-injury (12:26).

And that the most important features and treatment of water (Jacuzzis) is to reduce the movement of parts of the alarm (How this), as well as the distribution of movement and strengthen control of the lumbar vertebrae and the water increases the patient's ability to control and reduce the frequent mistakes in the movement on the use of exercises on land.

And that the use of rehabilitation and the treatment of water (Jacuzzi) has a positive effect on the improvement of the level of muscle strength and flexibility in patients with sliding cartilage of the lumbar and thus reduce the level of non-infected and thus has achieved the third hypothesis of the research, which states that - there are significant differences between the averages of pre measurements And the dimension of elasticity of the spinal column of patients with lumbar cartilage

\section{Conclusions}

-The proposed program, using rehabilitation and hydrotherapy exercises, reduced the pain index in patients with lumbar disc herniation.

-The proposed program, using rehabilitation and hydrotherapy exercises, improved the muscle strength of the muscles working on the spine in patients with lumbar cartilage.

-The proposed program, using rehabilitation exercises and hydrotherapy, has improved the flexibility of the spine in patients with lumbar cartilage.

\section{Recommendations}

-Use of the proposed program using rehabilitation exercises and hydrotherapy (Jacuzzi) because of its positive impact on the speed of access to the lips of the muscles working on the spine in patients with lumbar cartilage.

-Guided by the proposed rehabilitation program in the treatment of slip injuries of cartilage of different degrees of lumbar.

-Conduct similar studies and research using the Center's training exercises on other injuries and different samples. 


\section{References}

1-Ahmed Mohamed Khaled: Physiotherapy Why ?, Al-Ahram Center for Publishing and Translation, C1, Cairo, 2000.

2-Ahmed Mohamed Sayed Ahmed: Effect of a proposed program for the rehabilitation of the muscles of the back after the removal of cartilage Lumbar, unpublished doctoral thesis, Faculty of Physical Education for Boys, Suez Canal University, 2006.

3-Anwar Fathi Abdullah: "Effect of a proposed water rehabilitation program on the efficiency of the work of nerve roots compressed as a result of lumbar spine cartilage first class", Master Thesis, Faculty of Physical Education, Helwan University, 2008

4-Azza Fouad Shura: Curvature of the spine and some physical and physical measurements and its relationship to lower back pain for the practices and non - practices of sports activity, Journal of Comprehensive Physical Education Research, Faculty of Physical Education for Girls, Zagazig, No. 8, July,

5-Baltic Conference: 6th Baltic Conference in Family Medicine September 6-8, 2007.

6-Bakry MK: Differential Methods of medical physical culture in case of hand trauma sports men state central order of lens physical culture Moscow, 2001.

7-Bassem Mohammed Khalil: "The Effect of a Proposed Water Rehabilitation Program on Exercises for Lower Back Pain Patients, Master Thesis, Faculty of Physical Education, Helwan University, 2009.

8-Bereukox AA \& Vaseleva AF: Sportevnay massage Fezkoltora E Eporta, Moskva, 2008.

9-Campello M, Nordin M, Weiser S.: Physical Exercise and Low Back Pain: A Review. Scandinavian Journal of Medicine \& Science in Sports, 6:63-72, 2006.

10-Fahey TD: Athletic training principles and practice, 1st, Ed Mayfield Publishing Company (August ) California.2008.

11-Fatima Abdel-Fattah El-Hamlawi: Treatment of mechanical low back pain caused by different degree of curvature of the lumbar area, $\mathrm{PhD}$ thesis, Faculty of Physical Therapy, Cairo, 2006.

12-Hassan Mohammed Alnawasrh: slipped cartilage in the lumbar region and its relation to some components and measurements of the body, the Fifth Scientific Conference of Research on Physical Education, Part I, April, 2004.

13-Hisham Mohamed Ezzat Abbas: Effect of the program of therapeutic exercises on the torque of the back muscles in the cases of chronic low back pain of physiotherapists, PhD thesis, Faculty of Physical Therapy, Cairo, 2010.

14-Ibrahim Hassan Yahya: muscles of central stability and its relation to the morphology of lumbar concubine for handball players, Master Thesis, Faculty of Physical Education, Helwan University, 2015

15-Izzat Mahmoud Kashef: training exercises for athletes and heart patients, the library of the Egyptian Renaissance, 2000.

16-Kazmena. AN: Rokavodstestvo V Travmatologe Moatsna Moskva, 2008.

17-Kisner C, \& Calby. LA: Therapeutic exercise, Foundations and techniques, Nd, edition, 2006.

18-Kowall MG, Kolk G, Nuber GW : Patellar taping in the treatment patellofemoral pain Am J Sports Med January 2006 vol. 24 no. 1 61-66.

19-Marcia K. Anderson, Malissa M: Sports Injure Management Lippincott Williams \& Wilkins Co, U.S.A, 2005.

20-Mercrs : Orthopedic, Surgery $9^{\text {th }}$, Edition, 2006.

21-Millar P: Sport injuries and their management Williams wilkins and associates petty limited, London, 2002, P32. 
22-Mr. Salem: Determining the prevalence of low back pain in the iron and steel plant, its causes and how to avoid it, 2003.

23-Mohamed Kadri Bakri: Sports Injuries and physical therapy and massage, Cairo, 2006.

24-Mohammed Qadri Bakri, Siham Al-Ghamra: Sports Injuries and Physical Rehabilitation, Dar Al-Marikh, 2005.

25-Mohamed Qadri Bakri: Foundations of Treatment of Injuries and Rehabilitation in Kinesi therapy, The First Scientific Conference of Sport and Globalization, Volume III, Cairo, 5-6 April 2001.

26-Mousirah Hassan Ahmed Darwish: The Effect of Different Surgical Procedures on Lumbar Cartilage on Lumbar Area Functions, Unpublished Doctoral Thesis, Faculty of Physiotherapy, Cairo University, 2000.

27-Nadia Abdel-Azim Fayez: Evaluation of Back Pain with Peripheral Nerve Pain, unpublished PhD thesis, Faculty of Physical Therapy, Cairo University, 2004.

28-Randolph, MK \&Darlene H: Management of common muscle skeletal disorders, $2^{\text {nd }}$, Ed, J, B, Lippincott Co, New York, 2000.

29-Roy, S. Iversen D \&Irvin R: Sport medicine prevention, evaluation management and rehabilitation, Prentice-hall, Inc, Englewood clip, New Jersey, 2003.

30-Omar Shukri Omar: The Effect of Specialized Professional Work on the Rates of Glaucoma Slip in Iron and Steel Workers in Alexandria, Journal of Studies and Research in Physical Education, Volume 2, Number 3, August 4, 2002.

31-Saleh Abdullah Al-Roubi: Shortage in Sports Injuries and Physical Therapy, Dar Al-Fikr Al-Arabi, First Edition, Amman, 2005.

32-Tariq M. Al-Khaleq Hussein: Characteristics of loading on the lumbar spine of the human in the healthy and patients with cartilage removal, Master Thesis, Faculty of Physical Therapy, Cairo, 2009.

33-Tarek Hassan Sinan: The first conference of the spine and back pain, the Arab Society for the treatment of the spine, Kuwait, Mona, 2009.

34-Wael Mohamed Mohamed Ibrahim: Effect of rehabilitation program with the use of some accompanying methods for patients with lumbar discoloration, unpublished doctoral thesis, Faculty of Physical Education for Boys, Alexandria University, 2007.

35-Wilder DG, Pope MH \& Frymoyer JW. The biomechanics of lumbar disc herniation and the effect overload and instability. J, Spinal, Discord, 1988, 1(1), 16-32. 